\title{
Flower Production, Fruit Set, and Physiology of Bell Pepper during Elevated Temperature and Vapor Pressure Deficit
}

\author{
Ami N. Erickson ${ }^{1}$ and Albert H. Markhart ${ }^{2}$ \\ Department of Horticulture Science, University of Minnesota, St. Paul, MN 55108
}

AdDitional INDEX wORDs. plant reproduction, gas exchange, water status, bell pepper, Capsicum annuum var. annuum

\begin{abstract}
Aвstract. High temperature reduces fruit set in bell pepper [Capsicum annuum L. var. annuum (Grossum Group)], and reduction of pepper productivity, resulting from high temperature, may be a direct effect of temperature or an indirect effect of water stress induced by increased vapor pressure deficits (VPDs) at high temperature. We evaluated responses of plant growth, reproduction, net photosynthesis $\left(P_{N}\right)$, chlorophyll fluorescence, predawn respiration, leaf water potential, and stomatal conductance of 'Ace' and 'Bell Boy' bell pepper to elevated temperature $\left(33^{\circ} \mathrm{C}\right)$ with increased VPD $(2.1 \mathrm{kPa})$ or elevated temperature with no increase in VPD $(1.1 \mathrm{kPa})$. VPD had no effect on flower number or fruit set and did not adversely influence the physiological processes measured. Therefore, deleterious effects of high temperature on pepper fruit set does not appear to be temperature induced water stress, but is more likely a direct temperature response. Elevated temperature decreased fruit set but not flower production. Gas exchange measurements suggest failure to set fruit was not due to reduced leaf photosynthesis.
\end{abstract}

Reduced fruit set during periods of high temperature has been documented for a wide variety of plant species including pepper (Capsicum annuum L.) (Khah and Passam, 1992; Konsens et al., 1991). In pepper, reduced fruit set is common when day temperatures are $\geq 32{ }^{\circ} \mathrm{C}$ (Rylski and Spigelman, 1982). Abscission of reproductive structures in pepper during periods of high temperatures reduces yield in the northeastern United States (Wien, 1990), Israel (Rylski and Spigelman, 1982), and Greece (Khah and Passam, 1992), where peppers are commonly grown in plastic or glass greenhouses year round.

High temperature influences many aspects of plant physiology and growth, which in turn may have a direct or indirect effect on fruit set. In tomato (Lycopersicon esculentum Mill.) and cowpea [Vigna unguiculata (L.) Walp. ssp. unguiculata], high temperature affects pollen development resulting in nonviable pollen and failure to set fruit (Peet and Bartholomew, 1996; Sato et al., 2000; Warrag and Hall, 1984). In pepper, reduced fruit set at high temperature has been associated with decreased concentrations of reducing sugars in flower buds and flowers (Aloni et al., 1991) and increased ethylene production (Aloni et al., 1994).

High temperature may reduce fruit set indirectly by increasing vapor pressure deficits (VPDs), which can result in water deficits. Increased VPD results in increased evaporation and transpiration from leaf surfaces (Larcher, 1995). If the VPD creates a water deficit within the plant, stomata will close and leaf water potential will decrease resulting in decreased photosynthesis (Nilsen and Orcutt, 1996). There is a paucity of research on effects of water deficit on pepper fruit set (Katerji et al., 1993). However, research on other crops such as wheat (Triticum aestivum L.) and soybean (Glycine max L.) has demonstrated reproductive sensitivity to water deficit during flower development and fruit set (Lalonde et

Received for publication 17 July 2000. Accepted for publication 19 June 2001 University of Minnesota journal series 001210055 . This paper is a portion of a dissertation submitted by A.N.E. in partial fulfillment for the PhD degree requirements. The cost of publishing this paper was defrayed in part by the payment of page charges. Under postal regulations, this paper therefore must hereby be marked advertisement solely to indicate this fact.

${ }^{1}$ Currently postdoctoral fellow, Department of Biology, Colorado State University, Fort Collins, CO 80523

${ }^{2}$ Professor. al., 1997; Westgate and Peterson, 1993) resulting in reduced grain yield and pod biomass, respectively. Determining whether increased VPD at high temperature contributes to losses in fruit production in pepper will provide impetus for studying mechanisms responsible for reduced yield resulting from high temperature, and may provide strategies for preventing pepper fruit loss. Therefore, the following experiments were conducted to determine A) whether reduced pepper fruit set is a direct result of high temperature or increased VPD induced by high temperature, B) if reduced fruit set at high temperature is due to decreased flower bud production, increased flower bud abscission, or increased flower abscission, and C) whether high temperatures and/or increased VPD have a detrimental influence on plant gas exchange and water relations.

\section{Materials and Methods}

Plant materials. 'Ace' and 'Bell Boy' bell peppers [Capsicum annuum var. annuum (Grossum Group)] were used in this investigation. 'Ace' was chosen for recognized heat tolerance (Turner and Wien, 1994; Wien et al., 1989), and 'Bell Boy', a commonly grown cultivar, was chosen for comparison. Seeds of 'Ace' and 'Bell Boy' were sown in $20 \mathrm{~cm}^{3}$ plug trays with StrongLite Germination media (Strong-Lite, Sepeca, Ill.) and germinated under mist at $25 \pm 4{ }^{\circ} \mathrm{C}$. After germination, seedlings were transplanted individually into 0.5 -L pots in Strong-Lite Soilless Universal Mix)(Strong-Lite) and were grown in a greenhouse at day/nights of $25 / 21^{\circ} \mathrm{C}$, under ambient light supplemented with $400 \mathrm{~W}$ high pressure sodium, high intensity discharge lighting for $14 \mathrm{~h}$ daily. Plants were watered bi-weekly and fertilized weekly with $1.1 \mathrm{~g} /$ plant of a $20.0 \mathrm{~N}-4.4 \mathrm{P}-16.6 \mathrm{~K}$ water soluble fertilizer (Peter's Lite, Fogelsville, Pa.). After temperature/VPD treatments commenced, as described in the treatment section, plants were watered daily and fertilized bi-weekly.

Treatments. The experiment was conducted twice (Expt.1 and Expt. 2) in different growth chambers over two time periods. Three growth chambers were used for each experiment with treatment settings of $25^{\circ} \mathrm{C}$ with a VPD of $1.1 \mathrm{kPa}$ [60\% relative humidity (RH)], $33^{\circ} \mathrm{C}$ with a VPD of $1.1 \mathrm{kPa}(75 \% \mathrm{RH})$, and 33 ${ }^{\circ} \mathrm{C}$ with a VPD of $2.1 \mathrm{kPa}(60 \% \mathrm{RH})$. When the first flower buds 
reached anthesis, $\approx 4$ to 6 weeks after germination, 15 (Expt.1) or 18 (Expt. 2) plants of each cultivar were potted into 3.2-L pots with Strong-Lite Soilless Universal Mix (Strong-Lite) and arranged randomly into three growth chambers (E15; Conviron, Controlled Environments, Inc., Winnipeg, Canada) with five (Expt. 1) or six (Expt. 2) plants per chamber. The three growth chambers were set initially at constant temperatures of $25 \pm 0.2^{\circ} \mathrm{C}$ with a 12 $\mathrm{h}$ photoperiod of $650 \pm 50 \mu \mathrm{mol} \cdot \mathrm{m}^{-2} \cdot \mathrm{s}^{-1}$ photosynthetic photon flux as measured at canopy level with a quantum flux sensor (LI189; LI-COR, Inc., Lincoln, Nebr.). Irradiation sources in each chamber consisted of a combination of two 1000-W metal halide and two 1000-W sodium high-intensity-discharge lamps. RH inside the chambers was $60 \% \pm 10 \%$, equivalent to a VPD of 1.1 $\mathrm{kPa}$. Plants were allowed to acclimatize to the growth chamber environment for 1 week (Expt.1) or 3 weeks (Expt. 2) before treatment initiation.

The effect of high temperature with stable or increased VPD was investigated by increasing temperatures to $33{ }^{\circ} \mathrm{C}$ in two chambers with increased VPD of $2.1 \mathrm{kPa}$ in one of the high temperature chambers. Temperature and $\mathrm{RH}$ were stable within the growth chambers with a SD of $0.5{ }^{\circ} \mathrm{C}$ and $4 \%$, respectively. Light, temperature, and $\mathrm{RH}$ were monitored regularly to verify treatment conditions. Sample size was five plants of each cultivar per treatment (Expt. 1) and six plants of each cultivar per treatment (Expt. 2). Treatment duration was increased from $18 \mathrm{~d}$ in Expt. 1 to $25 \mathrm{~d}$ in Expt. 2 to allow more time for fruit set.

Growth Analysis. Reproductive structures were recorded every 3 to $5 \mathrm{~d}$. Data collected consisted of flower buds (visible buds which had not opened), mature flowers (flowers which were open, at anthesis or senescing), or fruit (fruitlets $\geq 2 \mathrm{~cm}$ in length).

To measure plant growth, leaf expansion was followed nondestructively by measuring the length and width of a leaf (tagged at $2 \mathrm{~cm}^{2}$ from the second or third node from the apical growing point at the initiation of experiment) for each plant throughout the experiment in Expt.1 only. Leaf area was determined using established regressions of length $\times$ width against leaf area, obtained with a leaf area meter (LI-3000; LI-COR, Inc.).

Physiological analysis. Leaf water potential and stomatal conductance were measured to determine whether high temperature and increased VPD changed plant water relations. Net photosynthesis $\left(\mathrm{P}_{\mathrm{N}}\right)$, chlorophyll fluorescence, and dark respiration were measured to determine if carbon limitation and injury to the photosynthetic apparatus occurred under the high temperature and/or increased VPD. These were recorded from the youngest, fully expanded leaves, one measurement per leaf and four measurements per leaf for chlorophyll fluorescence.

Water status. Water potential was determined using a Scholander-type pressure bomb (Soil Moisture Equip. Corp., Santa Barbara, Calif.). One leaf per plant of equal size from the third to fourth node from the apical growing point was collected $6 \mathrm{~h}$ into the photoperiod (middle of photoperiod) and placed immediately into a plastic bag, which was then sealed. Water potentials were determined on days 5 and 12 (Expt. 1) and days 3 and 11 (Expt. 2).

Stomatal conductance was determined using an AP4 Porometer (Delta-T Devices, Ltd., Cambridge, United Kingdom) in Expt. 1 or a Ciras-1 Portable Photosynthesis System (PP Systems, Haverhill, Mass.) in Expt. 2. Measurements were taken from one leaf per plant between hours $2(1000 \mathrm{HR})$ and $5(1300 \mathrm{HR})$ of the 12 $\mathrm{h}$ photoperiod on day 18 for Expt. 1 and on days 3 and 11 during Expt. 2.

Pнотosynthesis. Photosynthetic measurements were made in
Expt. 2 only. Rates of $\mathrm{CO}_{2}$ exchange were measured with a portable infrared gas analyzer (Ciras-1 Portable Photosynthesis System) to determine net photosynthetic rates $\left(\mathrm{P}_{\mathrm{N}}\right)$. Data were collected from one leaf of each plant between hours 2 and 5 of the 12-h photoperiod on days 3 and 11 .

Chlorophyll fluorescence yield was determined with an OS500 OPTI-Sciences Modulated Fluorometer (PP Systems). Fluorescence yield, also termed the potential yield of photochemistry, is the difference between the level of chlorophyll fluorescence when all Photosytem II (PSII) centers are open $\left(\mathrm{F}_{m}\right)$ and the maximum level of chlorophyll fluorescence when all PSII centers are closed $\left(\mathrm{F}_{o}\right)$, divided by $\mathrm{F}_{m}$ [i.e., $\left.\left(\mathrm{F}_{o}-\mathrm{F}_{m}\right) / \mathrm{F}_{m}\right]$ (Horton and Bowyer, 1990). Fluorometer parameters were set at a modulation of 180, saturation of 230 with a duration of $0.8 \mathrm{~s}$, and a detector gain of 65 . Photosynthetically active radiation and temperature sensors were also used. Data were collected from four leaves for each plant during the middle of the photoperiod under full light conditions on days 3 and 11.

Predawn dark Respiration. Dark respiration was determined only in Expt. 2 by measuring rates of $\mathrm{CO}_{2}$ exchange in predawn conditions, using a portable infrared gas analyzer (LI-6400; LICOR). Data were collected from one leaf per plant on days 14 and 19. All measurements were taken 1 to 2 hours before dawn.

Statistical analysis. Floral data for Expts. 1 and 2 were analyzed separately due to age differences of the plants. Without replication of treatments, the error term for temperature and VPD is underestimated (Potvin and Tardif, 1988). Therefore, only treatment effects, which were significant for both experiments were considered significant. Flower bud number, mature flower number, fruit number, and number of total reproductive structures from days 0 to day 15 were analyzed with a repeated measure multivariate analysis of variance (MANOVA). Pillai's Trace was used to determine significant factor effects (von Ende, 1993). Only $4 \mathrm{~d}$ were included in the analysis to increase power of the test. For Expt. 1 days 0, 3, 9, and 15 were used, and in Expt. 2 days $0,5,9$, and 15 were used. Treatments of $33^{\circ} \mathrm{C}$ at a VPD of $1.1 \mathrm{kPa}$ and $33^{\circ} \mathrm{C}$ at a VPD of $2.1 \mathrm{kPa}$ were compared in a separate repeated MANOVA, as were treatments $25^{\circ} \mathrm{C}$ at a VPD of $1.1 \mathrm{kPa}$ and $33^{\circ} \mathrm{C}$ at a VPD of $1.1 \mathrm{kPa}$ to separate VPD and temperature effects. A Bonferonni adjustment, $\mathrm{a}=0.05 / 2=0.025$, was used to determine significant effects (Scheiner, 1993).

Leaf growth was analyzed with a two-way (cultivar x treatment) repeated-measure analysis of variance (ANOVA). Leaf water potential, recorded in both experiments, was pooled as replicates and analyzed with a two-way repeated measure ANOVA. Stomatal conductance was log transformed to normalize the distribution prior to analysis. Tukey-Kramer HSD was used for all pairwise comparisons with a $P<0.05$. Tukey-Kramer HSD comparison uses a higher quantile for calculation of least significant difference (LSD) values, and thus is more conservative than Tukey's studentized range test (Sall and Lehman, 1996). All analyses were completed using statistical analysis software JMP version 3 (SAS Inst., Inc., Cary, N.C.).

\section{Results}

Flower ANd Fruit Production. VPD did not influence the number of flower buds, mature flowers, total reproductive structures, or fruit (Table 1). Temperature, however, significantly affected fruit set (Table 2). Plants grown at $33^{\circ} \mathrm{C}$ at either VPD failed to set fruit, while plants grown at $25^{\circ} \mathrm{C}$ began to set fruit within $9 \mathrm{~d}$ of the beginning of the experiment and continued 
setting fruit up to termination of the experiment (Fig. 1). Flower bud number (Fig. 2), mature flower number (Fig. 3), and total reproductive structures (data not presented) were not affected by temperature, when temperature was considered for the entire experiment (Table 2; between subjects).

To determine if lack of fruit set at the high temperature treatments was due to a delay of fruit production, plants in Expt. 2 were grown for a longer period at the treatment temperatures to allow more time for fruit production. While plants at $25^{\circ} \mathrm{C}$ with a VPD at $1.1 \mathrm{kPa}$ in Expt. 2 continued to produce fruit, the number of flower buds decreased greatly from a mean of 102.3/plant for 'Ace' $5 \mathrm{~d}$ before fruit set (day 9) to a mean of 23.8/plant $7 \mathrm{~d}$ after fruit set had begun (day 22). 'Bell Boy' responded similarly with an increase in fruit set and a great decrease in flower bud number at the control temperature of $25^{\circ} \mathrm{C}$ with a VPD at $1.1 \mathrm{kPa}$. Plants at $33^{\circ} \mathrm{C}$ continued producing flower buds throughout the experiment. 'Ace,' grown at $33^{\circ} \mathrm{C}$ with a VPD of $1.1 \mathrm{kPa}$, had a mean

Table 1. MANOVA of flower bud number, mature flower number, and total reproductive structures per plant of 'Ace' and 'Bell Boy' bell pepper for the treatment period with repeated measure of Expts. 1 and 2, comparing treatments of $33^{\circ} \mathrm{C}$ at a VPD of $1.1 \mathrm{kPa}$ vs. $33^{\circ} \mathrm{C}$ at a VPD of $2.1 \mathrm{kPa}$. Individual plants are subjects. No fruit were produced at the $33^{\circ} \mathrm{C}$ treatments. Values presented are $P$ values with the numerator/denominator df. Bonferroni adjustment maintains that $\alpha=0.025$ (Scheiner, 1993).

\begin{tabular}{|c|c|c|}
\hline \multirow[b]{3}{*}{ Source } & \multicolumn{2}{|c|}{ Treatment (temp/VPD) } \\
\hline & $33^{\circ} \mathrm{C} / 1.1 \mathrm{kPa}$ & $33^{\circ} \mathrm{C} / 2.1 \mathrm{kPa}$ \\
\hline & $\begin{array}{c}\text { Expt. } 1 \\
{[P \text { value }(\mathrm{df})]}\end{array}$ & $\begin{array}{c}\text { Expt. } 2 \\
{[P \text { value }(\mathrm{df})]}\end{array}$ \\
\hline \multicolumn{3}{|l|}{ Flower buds } \\
\hline \multicolumn{3}{|l|}{ Between subjects } \\
\hline Treatment (Trt) & $0.220(1 / 16)$ & $0.341(1 / 20)$ \\
\hline Cultivar $(\mathrm{Cv})$ & $0.002(1 / 16)$ & $0.030(1 / 20)$ \\
\hline $\operatorname{Trt} \times \mathrm{Cv}$ & $0.322(1 / 16)$ & $0.050(1 / 20)$ \\
\hline \multicolumn{3}{|l|}{ Within subjects } \\
\hline Time $(\mathrm{T})$ & $<0.001(3 / 14)$ & $<0.001(3 / 18)$ \\
\hline $\mathrm{T} \times \mathrm{Trt}$ & $0.117(3 / 14)$ & $0.378(3 / 18)$ \\
\hline $\mathrm{T} \times \mathrm{Cv}$ & $0.008(3 / 14)$ & $<0.001(3 / 18)$ \\
\hline $\mathrm{T} \times \mathrm{Trt} \times \mathrm{Cv}$ & $0.430(3 / 14)$ & $0.359(3 / 18)$ \\
\hline \multicolumn{3}{|l|}{ Mature flowers } \\
\hline \multicolumn{3}{|l|}{ Between subjects } \\
\hline Trt & $0.611(1 / 16)$ & $0.686(1 / 20)$ \\
\hline $\mathrm{Cv}$ & $0.008(1 / 16)$ & $0.005(1 / 20)$ \\
\hline $\mathrm{Trt} \times \mathrm{Cv}$ & $0.048(1 / 16)$ & $0.075(1 / 20)$ \\
\hline \multicolumn{3}{|l|}{ Within subjects } \\
\hline $\mathrm{T}$ & $<0.001(3 / 14)$ & $<0.001(3 / 18)$ \\
\hline $\mathrm{T} \times \mathrm{Trt}$ & $0.609(3 / 14)$ & $0.530(3 / 18)$ \\
\hline $\mathrm{T} \times \mathrm{Cv}$ & $0.092(3 / 14)$ & $0.002(3 / 18)$ \\
\hline $\mathrm{T} \times \operatorname{Trtr} \times \mathrm{Cv}$ & $0.392(3 / 14)$ & $0.143(3 / 18)$ \\
\hline \multicolumn{3}{|c|}{ Total reproductive structures } \\
\hline \multicolumn{3}{|c|}{ Between subjects } \\
\hline Trt & $0.276(1 / 16)$ & $0.538(1 / 20)$ \\
\hline $\mathrm{Cv}$ & $0.001(1 / 16)$ & $0.117(1 / 20)$ \\
\hline $\operatorname{Trt} \times \mathrm{Cv}$ & $0.242(1 / 16)$ & $0.060(1 / 20)$ \\
\hline \multicolumn{3}{|l|}{ Within subjects } \\
\hline $\mathrm{T}$ & $<0.001(3 / 14)$ & $<0.001(3 / 18)$ \\
\hline $\mathrm{T} \times \mathrm{Trt}$ & $0.101(3 / 14)$ & $0.382(3 / 18)$ \\
\hline $\mathrm{T} \times \mathrm{Cv}$ & $<0.001(3 / 14)$ & $0.076(3 / 18)$ \\
\hline $\mathrm{T} \times \mathrm{Trt} \times \mathrm{Cv}$ & $0.405(3 / 14)$ & $0.486(3 / 18)$ \\
\hline
\end{tabular}

of 92.2 flower buds/plant on day 22, and 'Bell Boy' grown at the same temperature had a mean of 63.7 flower buds on day 22. Both cultivars failed to set fruit at $33{ }^{\circ} \mathrm{C}$ even after $25 \mathrm{~d}$ of temperature exposure (data not presented).

LEAF AREA. Leaf area of tagged leaves measured throughout Expt. 1 as shown in Fig. 4 did not differ significantly among treatments $(P=0.32)$. Leaves continued to expand at the same rate until day 14 for all treatments. Leaves of 'Bell Boy' expanded at

Table 2. MANOVA of flower bud number, mature flower number, total reproductive structures, and fruit number per plant of 'Ace' and 'Bell Boy' bell pepper for the treatment period with repeated measure of Expts. 1 and 2, comparing temperature treatments of $25^{\circ} \mathrm{C}$ at a VPD of $1.1 \mathrm{kPa}$ vs. $33^{\circ} \mathrm{C}$ at a VPD of $1.1 \mathrm{kPa}$. Individual plants are subjects. No fruit were produced at the $33^{\circ} \mathrm{C}$ treatment. Values shown are $P$ values with the numerator/denominator $\mathrm{df}$. Bonferroni adjustment maintains that $\alpha=0.025$ (Scheiner, 1993).

\begin{tabular}{|c|c|c|}
\hline \multirow[b]{3}{*}{ Source } & \multicolumn{2}{|c|}{ Treatment (temp/VPD) } \\
\hline & $33^{\circ} \mathrm{C} / 1.1 \mathrm{kPa}$ & $33^{\circ} \mathrm{C} / 2.1 \mathrm{kPa}$ \\
\hline & $\begin{array}{c}\text { Expt. } 1 \\
{[P \text { value }(\mathrm{df})]}\end{array}$ & $\begin{array}{c}\text { Expt. } 2 \\
{[P \text { value }(\mathrm{df})]}\end{array}$ \\
\hline \multicolumn{3}{|l|}{ Flower buds } \\
\hline \multicolumn{3}{|l|}{ Between subjects } \\
\hline Treatment (Trt) & $0.127(1 / 16)$ & $0.208(1 / 20)$ \\
\hline Cultivar (Cv) & $0.014(1 / 16)$ & $0.038(1 / 20)$ \\
\hline $\operatorname{Trt} \times \mathrm{Cv}$ & $0.470(1 / 16)$ & $0.321(1 / 20)$ \\
\hline \multicolumn{3}{|l|}{ Within subjects } \\
\hline Time $(\mathrm{T})$ & $<0.001(3 / 14)$ & $<0.001(3 / 18)$ \\
\hline $\mathrm{T} \times \mathrm{Trt}$ & $0.493(3 / 14)$ & $<0.001(3 / 18)$ \\
\hline $\mathrm{T} \times \mathrm{Cv}$ & $0.035(3 / 14)$ & $0.265(3 / 18)$ \\
\hline $\mathrm{T} \times \mathrm{Trt} \times \mathrm{Cv}$ & $0.681(3 / 14)$ & $0.003(3 / 18$ \\
\hline \multicolumn{3}{|l|}{ Mature flowers } \\
\hline \multicolumn{3}{|l|}{ Between subjects } \\
\hline Trt & $0.168(1 / 16)$ & $0.284(1 / 20)$ \\
\hline $\mathrm{Cv}$ & $0.255(1 / 16)$ & $0.284(1 / 20)$ \\
\hline $\operatorname{Trt} \times \mathrm{Cv}$ & $0.699(1 / 16)$ & $0.038(1 / 20)$ \\
\hline \multicolumn{3}{|l|}{ Within subjects } \\
\hline $\mathrm{T}$ & $<0.001(3 / 14)$ & $<0.001(3 / 18)$ \\
\hline $\mathrm{T} \times \mathrm{Trt}$ & $0.200(3 / 14)$ & $<0.001(3 / 18)$ \\
\hline $\mathrm{T} \times \mathrm{Cv}$ & $0.126(3 / 14)$ & $0.240(3 / 18)$ \\
\hline $\mathrm{T} \times \mathrm{Trt} \times \mathrm{Cv}$ & $0.965(3 / 14)$ & $0.019(3 / 18)$ \\
\hline \multicolumn{3}{|c|}{ Total reproductive structures } \\
\hline \multicolumn{3}{|c|}{ Between subjects } \\
\hline Trt & $0.115(1 / 16)$ & $0.174(1 / 20)$ \\
\hline $\mathrm{Cv}$ & $0.009(1 / 16)$ & $0.051(1 / 20)$ \\
\hline $\mathrm{Trt} \times \mathrm{Cv}$ & $0.488(1 / 16)$ & $0.674(1 / 20)$ \\
\hline \multicolumn{3}{|l|}{ Within subjects } \\
\hline $\mathrm{T}$ & $<0.001(3 / 14)$ & $<0.001(3 / 18)$ \\
\hline $\mathrm{T} \times \mathrm{Trt}$ & $0.491(3 / 14)$ & $0.002(3 / 18)$ \\
\hline $\mathrm{T} \times \mathrm{Cv}$ & $0.014(3 / 14)$ & $0.398(3 / 18)$ \\
\hline $\mathrm{T} \times \mathrm{Trt} \times \mathrm{Cv}$ & $0.489(3.14)$ & $0.223(3 / 18)$ \\
\hline \multicolumn{3}{|l|}{ Fruit number } \\
\hline \multicolumn{3}{|l|}{ Between subjects } \\
\hline Trt & $<0.001(1 / 16)$ & $<0.001(1 / 20)$ \\
\hline $\mathrm{Cv}$ & $0.444(1 / 16)$ & $0.068(1 / 20)$ \\
\hline $\mathrm{Trt} \times \mathrm{Cv}$ & $0.444(1 / 16)$ & $0.035(1 / 20)$ \\
\hline \multicolumn{3}{|l|}{ Within subjects } \\
\hline $\mathrm{T}$ & $0.004(3 / 14)$ & $<0.001(3 / 18)$ \\
\hline $\mathrm{T} \times \mathrm{Trt}$ & $0.004(3 / 14)$ & $<0.001(3 / 18)$ \\
\hline $\mathrm{T} \times \mathrm{Cv}$ & $0.004(3 / 14)$ & $0.191(3 / 18)$ \\
\hline $\mathrm{T} \times \mathrm{Trt} \times \mathrm{Cv}$ & $0.004(3 / 14)$ & $0.238(3 / 18)$ \\
\hline
\end{tabular}



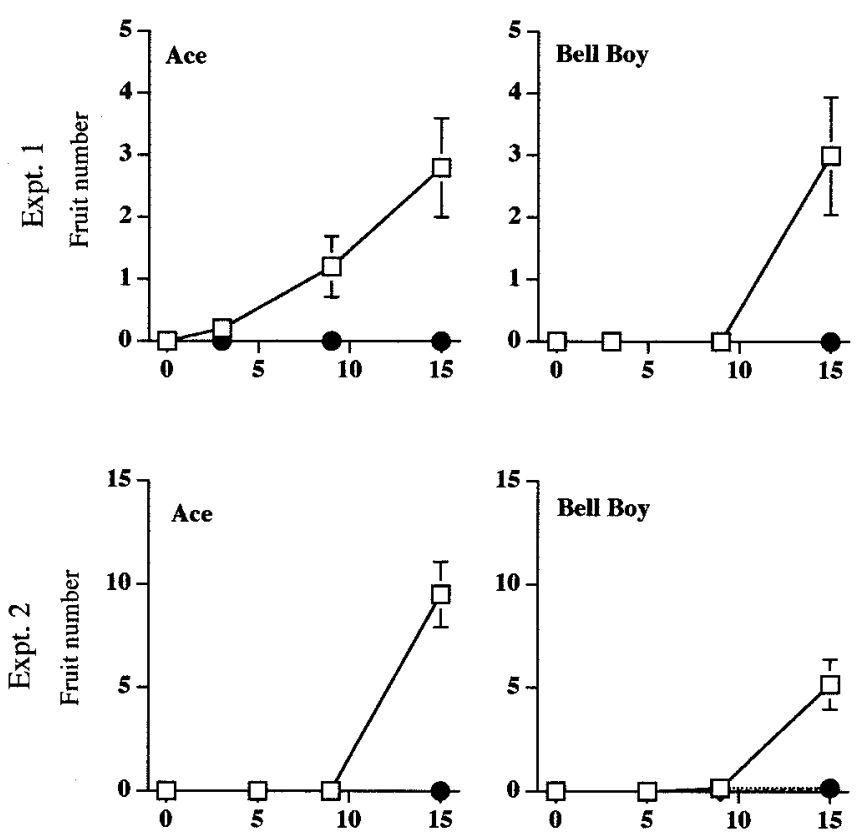

Time (days)

Fig. 1. Fruit number per plant of 'Ace' and 'Bell Boy' bell peppers grown at 25 ${ }^{\circ} \mathrm{C}$ with a VPD of $1.1 \mathrm{kPa}(\square), 33^{\circ} \mathrm{C}$ with a VPD of $1.1 \mathrm{kPa}$, or $33^{\circ} \mathrm{C}$ at a VPD of $2.1 \mathrm{kPa}(\bullet)$ in two experiments. Fruit number from treatments $33^{\circ} \mathrm{C}$ with a VPD of $1.1 \mathrm{kPa}$ and $33^{\circ} \mathrm{C}$ with a VPD of $2.1 \mathrm{kPa}$ are identical and, thus, shown with the same symbol. Vertical bars $=\operatorname{sE}($ Expt. $1: \mathrm{n}=$ five plants; Expt. $2: \mathrm{n}=$ six plants).
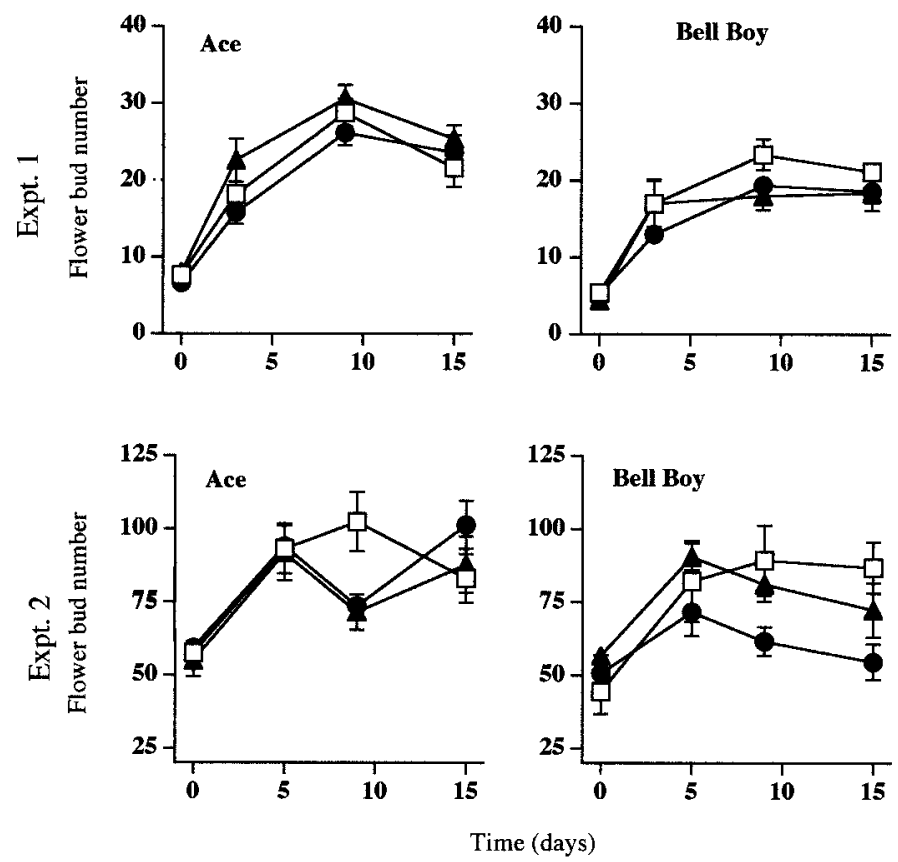

Fig. 3. Mature flower number per plant of 'Ace' and 'Bell Boy' bell peppers grown at $25^{\circ} \mathrm{C}$ with a VPD of $1.1 \mathrm{kPa}(\square), 33^{\circ} \mathrm{C}$ with a VPD of $1.1 \mathrm{kPa}(\mathbf{O})$, or $33^{\circ} \mathrm{C}$ with a VPD of $2.1 \mathrm{kPa}(\boldsymbol{\Delta})$ in two experiments. Vertical bars = sE (Expt $1: \mathrm{n}=$ five plants; Expt 2: $\mathrm{n}=$ six plants).

a slightly higher rate than 'Ace', (day $\times$ cultivar, $P<0.001$ ).

Water status. Water potentials were significantly more negative at the higher temperature $(P<0.001)$ from a mean of -0.59 $\mathrm{MPa}$ at $25{ }^{\circ} \mathrm{C}$ to $-0.9 \mathrm{MPa}$ at $33{ }^{\circ} \mathrm{C}$ (Table 3). Date of data
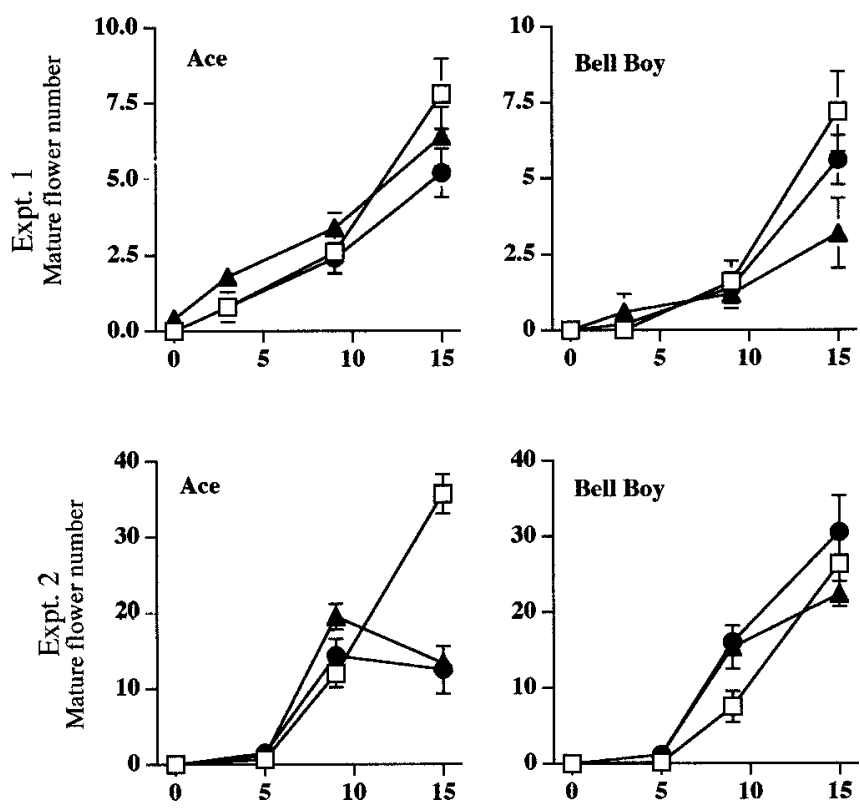

Time (days)

Fig. 2. Flower bud number per plant of 'Ace' and 'Bell Boy' bell peppers grown at $25^{\circ} \mathrm{C}$ with a VPD of $1.1 \mathrm{kPa}(\square), 33^{\circ} \mathrm{C}$ with a VPD of $1.1 \mathrm{kPa}(\mathbf{O})$, or $33^{\circ} \mathrm{C}$ with a VPD of $2.1 \mathrm{kPa}(\boldsymbol{\Delta})$ in two experiments. Vertical bars $=$ SE $($ Expt $1: \mathrm{n}=$ five plants; Expt 2: n = six plants).

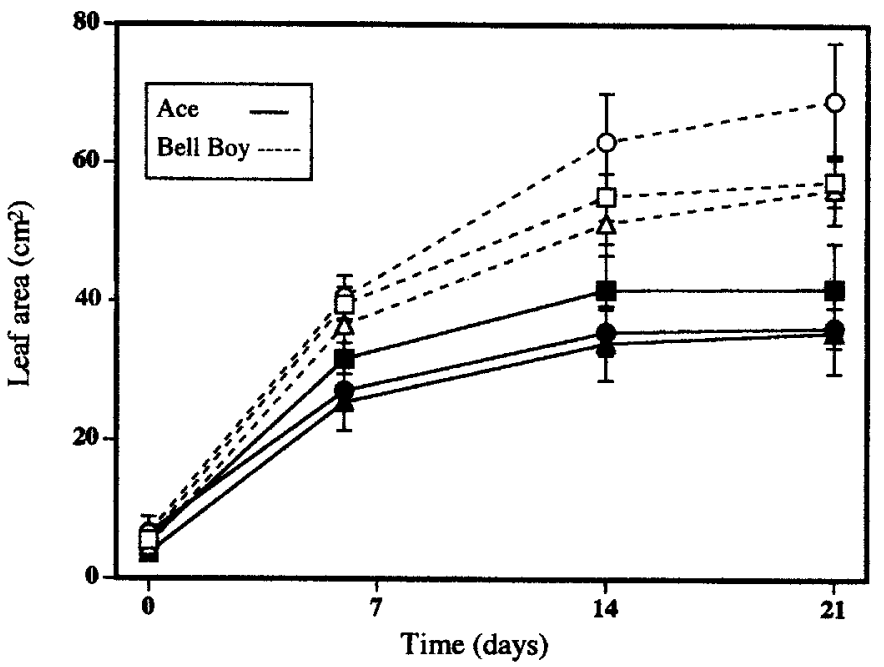

Fig. 4. Leaf area of 'Ace'(solid symbols, solid lines) and 'Bell Boy' (open symbols, dashed lines) bell pepper plants over the course of $21 \mathrm{~d}$ at $25^{\circ} \mathrm{C}$ with a VPD of $1.1 \mathrm{kPa}(\boldsymbol{\square}), 33^{\circ} \mathrm{C}$ with a VPD of $1.1 \mathrm{kPa}(\mathbf{O})$, or $33^{\circ} \mathrm{C}$ with a VPD of $2.1 \mathrm{kPa}(\mathbf{\Delta})$. Vertical bars $=\mathrm{SE}(\mathrm{n}=$ five plants $)$.

collection did not interact with treatment effects $(P=0.39)$, and cultivars responded similarly to the treatments (cultivar $\times$ treatment, $P=0.44$ ). Data for the $2 \mathrm{~d}$ as well as the two cultivars were pooled for pairwise comparison. Water potentials did not significantly differ between the two VPDs at high temperatures.

For both experiments, stomatal conductance of plants at $33^{\circ} \mathrm{C}$ was higher than that at $25^{\circ} \mathrm{C}(P<0.001)$, but did not differ consistently between either VPD (Table 3). 'Ace' and 'Bell Boy' responded similarly $[P=0.68$ (Expt.1); $P=0.69$ (Expt. 2$)]$ and cultivar data were pooled for analysis.

Photosynthetic measurements. Net photosynthetic rates were significantly higher at the high temperature $(P<0.001)$ 
Table 3. Leaf water potential $(\Psi)$ and nontransformed stomatal conductance of youngest, fully expanded leaves of 'Ace' and 'Bell Boy' bell pepper grown at $25^{\circ} \mathrm{C}$ at a VPD of $1.1 \mathrm{kPa}, 33^{\circ} \mathrm{C}$ at a VPD of $1.1 \mathrm{kPa}$, or $33{ }^{\circ} \mathrm{C}$ at a VPD of $2.1 \mathrm{kPa}$.

\begin{tabular}{|c|c|c|c|}
\hline \multirow{2}{*}{$\begin{array}{l}\text { Treatment } \\
\text { (temp/VPD) }\end{array}$} & \multirow{2}{*}{$\begin{array}{l}\text { Water potential }(\Psi) \\
(\mathrm{MPa})^{\mathrm{z}}\end{array}$} & \multicolumn{2}{|c|}{$\begin{array}{l}\text { Stomatal conductance } \\
\left(\mathrm{H}_{2} \mathrm{O}, \mathrm{mmol} \cdot \mathrm{m}^{-2} \cdot \mathrm{s}^{-1}\right)^{\mathrm{y}}\end{array}$} \\
\hline & & Expt. 1 & Expt. 2 \\
\hline $25^{\circ} \mathrm{C} / 1.1 \mathrm{kPa}$ & $-0.59 \mathrm{a}^{\mathrm{x}}$ & $345.1 \mathrm{a}$ & $163.3 \mathrm{a}$ \\
\hline $33^{\circ} \mathrm{C} / 1.1 \mathrm{kPa}$ & $-0.90 \mathrm{~b}$ & $571.7 \mathrm{a}$ & $691.1 \mathrm{c}$ \\
\hline $33^{\circ} \mathrm{C} / 2.1 \mathrm{kPa}$ & $-0.88 \mathrm{~b}$ & $1184.5 \mathrm{~b}$ & $420.8 \mathrm{~b}$ \\
\hline
\end{tabular}

${ }^{\mathrm{Z}}$ Water potential values are means of one-way ANOVA of treatments with pooled data from $2 \mathrm{~d}$ of data collection of two experiments with 'Ace' and 'Bell Boy' bell pepper.

'Stomatal conductance values are means from one-way ANOVA of treatments with pooled data from $2 \mathrm{~d}$ of data collection with the two cultivars, but the two experiments are kept separate due to a significant experiment $\times$ treatment interaction.

${ }^{x}$ Mean separation within columns by Tukey-Kramer HSD $(P<0.05)$ (Sall and Lehman, 1996).

Table 4. Net photosynthesis $\left(\mathrm{P}_{\mathrm{N}}\right)$ and chlorophyll fluorescence (yield) of youngest, fully expanded leaves of 'Ace' and 'Bell Boy' bell pepper grown at $25^{\circ} \mathrm{C}$ at a VPD of $1.1 \mathrm{kPa}, 33^{\circ} \mathrm{C}$ at a VPD of $1.1 \mathrm{kPa}$, or 33 ${ }^{\circ} \mathrm{C}$ at a VPD of $2.1 \mathrm{kPa}$. Values are pooled means from cultivars and $2 \mathrm{~d}$ of data collection.

\begin{tabular}{lcc}
\hline \hline $\begin{array}{l}\text { Treatment } \\
\text { (temp/VPD) }\end{array}$ & $\begin{array}{c}\mathrm{P}_{\mathrm{N}} \\
\left(\mathrm{CO}_{2}, \mu \mathrm{mol} \cdot \mathrm{m}^{-2} \cdot \mathrm{s}^{-1}\right)\end{array}$ & $\begin{array}{c}\text { Chlorophyll } \\
\text { fluorescence } \\
\text { (yield) }\end{array}$ \\
\hline $25^{\circ} \mathrm{C} / 1.1 \mathrm{kPa}$ & $9.7 \mathrm{a}^{\mathrm{z}}$ & $0.64 \mathrm{a}$ \\
$33^{\circ} \mathrm{C} / 1.1 \mathrm{kPa}$ & $11.6 \mathrm{~b}$ & $0.67 \mathrm{~b}$ \\
$33^{\circ} \mathrm{C} / 2.1 \mathrm{kPa}$ & $13.2 \mathrm{c}$ & $0.67 \mathrm{~b}$
\end{tabular}

${ }^{\mathrm{z}}$ Mean separation within columns by Tukey-Kramer HSD $(P<0.05)$ (Sall and Lehman, 1996).

Table 5. Predawn dark respiration responses of youngest, fully expanded leaves of 'Ace' and 'Bell Boy' bell peppers grown at $25^{\circ} \mathrm{C}$ with a VPD of $1.1 \mathrm{kPa}, 33^{\circ} \mathrm{C}$ with a VPD of $1.1 \mathrm{kPa}$, or $33^{\circ} \mathrm{C}$ with a VPD of $2.1 \mathrm{kPa}$. Values are means of six plants.

\begin{tabular}{lccc}
\hline \hline & $\begin{array}{c}\text { Treatment } \\
\text { Cultivar }\end{array}$ & \multicolumn{2}{c}{$\begin{array}{c}\text { Respiration rate } \\
\left(\mathrm{CO}_{2}, \mu \mathrm{mol} \cdot \mathrm{m}^{-2} \cdot \mathrm{s}^{-1}\right)\end{array}$} \\
\cline { 3 - 4 } Ace & $25^{\circ} \mathrm{C} / 1.1 \mathrm{kPa}$ & $1.7 \mathrm{a}^{\mathrm{y}}$ & $19 \mathrm{DAT}$ \\
& $33^{\circ} \mathrm{C} / 1.1 \mathrm{kPa}$ & $1.2 \mathrm{~b}$ & $1.8 \mathrm{a}$ \\
Bell Boy & $33^{\circ} \mathrm{C} / 2.1 \mathrm{kPa}$ & $1.3 \mathrm{~b}$ & $1.6 \mathrm{a}$ \\
& $25^{\circ} \mathrm{C} / 1.1 \mathrm{kPa}$ & $2.0 \mathrm{a}$ & $1.9 \mathrm{a}$ \\
& $33^{\circ} \mathrm{C} / 1.1 \mathrm{kPa}$ & $1.1 \mathrm{~b}$ & $1.3 \mathrm{~b}$ \\
& $33^{\circ} \mathrm{C} / 2.1 \mathrm{kPa}$ & $1.3 \mathrm{~b}$ & $1.2 \mathrm{~b}$
\end{tabular}

${ }^{\mathrm{z}} \mathrm{DAT}=$ days after treatment began.

${ }^{\mathrm{y}}$ Mean separation within columns for a cultivar by Tukey-Kramer HSD $(P<0.05)$ (Sall and Lehman, 1996).

(Table 4). Cultivars responded similarly $(P=0.11)$, and $P_{\mathrm{N}}$ was not affected by time $(P=0.59) . \mathrm{P}_{\mathrm{N}}$ increased from $25^{\circ} \mathrm{C}$ by $18 \%$ at $33{ }^{\circ} \mathrm{C}$ with a VPD of $1.1 \mathrm{kPa}$ and by $35 \%$ at $33^{\circ} \mathrm{C}$ with a VPD of $2.1 \mathrm{kPa}$.

Chlorophyll Fluorescence measurements. Chlorophyll fluorescence yield increased by 5\% at the higher temperatures $(P$ $<0.001$ ) (Table 4). Yields did not differ among VPD treatments. Cultivars responded similarly to treatments $(P=0.28)$, and fluorescence was not affected by time $(P=0.06)$.
DARK RESPIRATION MEASUREMENTS. Predawn leaf dark respiration rates decreased from $8 \%$ to $38 \%$ at $33^{\circ} \mathrm{C}(P<0.001)$ (Table $5)$. However, respiration rates did not differ between VPD treatments. Respiration rates responded differently to the treatment between the $2 \mathrm{~d}$ of data collection (treatment $\times$ day, $P<0.001$ ). Therefore, results are presented separately for the $2 \mathrm{~d}$ and two cultivars.

\section{Discussion}

No effect of increased VPD on flower production, fruit set, or leaf expansion of 'Ace' and 'Bell Boy' bell pepper was observed at $33{ }^{\circ} \mathrm{C}$. High temperature influenced leaf water potential, stomatal conductance, $\mathrm{P}_{\mathrm{N}}$, chlorophyll fluorescence, and predawn leaf respiration, and it completely inhibited fruit set, independently of VPD.

Although flower bud number was similar at $33^{\circ} \mathrm{C}$ (Fig. 2), and many buds reached the mature flower stage (Fig. 3), fruit set was inhibited completely (Fig. 1). While flowers developing at high temperature generally opened fully, the flowers did not shed pollen. Failure of peppers to set fruit at $33^{\circ} \mathrm{C}$ was due to abscission of mature flowers, possibly after a malfunction in flower development, such as incomplete microspore meiosis, resulting in nonfertilized flowers.

Plant water status was affected more by high temperature than VPD. Decreased water potentials suggest that plants were under some water stress at the high temperature (Table 3). However, stomatal conductances increased (Table 3), suggesting water was not limiting. Increases in stomatal conductances were most likely related to increases in $\mathrm{P}_{\mathrm{N}}$ at the high temperature (Table 4).

Dark respiration increases exponentially with increased temperatures (Larcher, 1995). However, our observations of an increase in $\mathrm{P}_{\mathrm{N}}$ and the decrease in predawn dark respiration at high temperatures (Table 5) are contrary. One explanation for the lower predawn dark respiration rates in the elevated temperature treatments may be that carbohydrate reserves were depleted by the end of the dark period. Respiration rates are dependent in part on carbohydrate availability; subsequently our measurements of predawn dark respiration suggest that carbohydrate availability may have been limiting by the end of the dark period. Therefore, the increase in $\mathrm{P}_{\mathrm{N}}$ may have been in response to increased demand for carbon assimilation in plants growing at high temperature. The increase in fluorescence yield suggests a change in the efficiency of photosynthesis at the high temperature. Direct measurements of diurnal carbohydrate levels and further examination of chlorophyll fluorescence are needed to test these hypotheses.

Plant organ respiration, assimilate levels, and partitioning have been associated with stress induced flower bud and flower abscission. Turner and Wien (1994) reported that dark respiration rates of flower buds decreased further under stress conditions in pepper cultivars susceptible to stress induced flower bud and flower abscission than respiration rates of stress resistant cultivars. Respiration rates of expanded leaves were higher under both control and stress conditions for stress susceptible cultivars than for stress resistant cultivars. Aloni et al. (1991) did not observe an effect of high day or night temperatures on photosynthetic rates of source leaves of pepper but observed that partitioning of $\left[{ }^{14} \mathrm{C}\right]$ sucrose to flower buds and flowers was reduced, while importation to young leaves increased. The presence of developing fruit further decreased sucrose importation to flowers. Our observation of increased $\mathrm{P}_{\mathrm{N}}$ of expanded leaves at $33{ }^{\circ} \mathrm{C}$ and the decrease 
of predawn dark respiration of leaves at $33{ }^{\circ} \mathrm{C}$ may support the hypothesis of Aloni et al. (1991) that leaves at high temperature maintain their assimilation rate at the expense of developing reproductive structures.

Data herein indicate that in bell pepper high temperature inhibits fruit set independently from VPD at the levels studied and at constant high temperature of $33{ }^{\circ} \mathrm{C}$. Vapor pressure deficits may have an effect on pepper productivity at lower temperatures, but the stress caused by the high temperature treatment masked any effect of the increased VPD. Inhibition of fruit set at high temperature is due primarily to abscission of mature flowers. We have observed (unpublished data) that high temperature directly affects pollen development. Although, carbon assimilation may play an important role in flower bud and flower abscission, we hypothesize that inhibition of fruit set at high temperature is most likely a direct effect of high temperature on flower development and perhaps fertilization.

\section{Literature Cited}

Aloni, B., L. Karni, Z. Zaidman, Y. Riov, M. Huberman, and R. Goren. 1994. The susceptibility of pepper (Capsicum annuum) to heat induced flower abscission: Possible involvement of ethylene. J. Hort. Sci. 69:923-928.

Aloni, B., T. Pashkar, and L. Karni. 1991. Partitioning of $\left[{ }^{14} \mathrm{C}\right]$ sucrose and acid invertase activity in reproductive organs of pepper plants in relation to their abscission under heat stress. Ann. Bot. 67:371-377.

Horton, P. and J.R Bowyer. 1990. Chlorophyll fluorescence transients, p 259-296. In: J.L. Harwood and J.R. Bowyer (eds.). Lipids, membranes and aspects of photobiology. Methods in plant biochemistry. vol. 4. Academic Press, San Diego.

Katerji, N., M. Mastrorilli, and A. Hamdy. 1993. Effects of water stress at different growth stages on pepper yield. Acta Hort. 335:165-171.

Khah, E.M. and H.C. Passam. 1992. Flowering, fruit set, and development of the fruit and seed of sweet pepper (Capsicum annuum L.) cultivated under conditions of high ambient temperature. J. Hort. Sci. 67:251-258.

Konsens, J., M. Ofir, and J. Kigel. 1991. The effect of temperature on the production and abscission of flowers and pods in snap bean (Phaseolus vulgaris L.). Ann. Bot. 6:391-399.

Lalonde, S., D.U. Beebe, and H.S. Saini. 1997. Early signs of disruption of wheat anther development associated with the induction of male sterility by meiotic-stage water deficit. Sexual Plant Reproduction 10:40-48.

Larcher,W. 1995. Physiological plant ecology. $3^{\text {rd }}$ ed. Springer-Verlag, New York.

Nilsen, E. and D. Orcutt. 1996. Physiology of plants under stress: Abiotic factors. Wiley, New York.

Peet, M.M. and M. Bartholmew. 1996. Effect of night temperature on pollen characteristics, growth, and fruit set in tomato. J. Amer. Soc. Hort. Sci. 121:514-519.

Potvin, C. and S. Tardif. 1988. Sources of variability and experimental designs in growth chambers. Functional Ecol. 2:123-130.

Rylski, I. and M. Spigelman. 1982. Effects of different diurnal temperature combinations on fruit set of sweet pepper. Scientia Hort. 17:101106.

Sall, J. and A. Lehman. 1996. JMP ${ }^{\circledR}$ start statistics: A guide to statistics and data analysis using JMP ${ }^{\circledR}$ and JMP IN ${ }^{\circledR}$ Software. Duxbury Press, Belmont, Calif.

Sato, S., M.M. Peet, and J.F. Thomas. 2000. Physiological factors limit fruit set of tomato (Lycopersicon esculentum Mill.) under chronic, mild heat stress. Plant, Cell, Environ. 23:719-726.

Scheiner, S. 1993. MANOVA: Multiple response variables and multispecies interactions, p. 94-112. In: S.M. Scheiner and J. Gurevitch (eds.). Design and analysis of ecological experiments. Intl. Thomson Publishing, New York.

Turner, A.D. and H.C. Wien. 1994. Photosynthesis, dark respiration and bud sugar concentrations in pepper cultivars differing in susceptibility to stress-induced bud abscission. Ann. Bot. 73:623-628.

von Ende, C. 1993. Repeated-measures analysis: Growth and other timedependent measures, p.113-137. In: S.M.Scheiner and J. Gurevitch (eds.). Design and analysis of ecological experiments. Intl. Thomson Publishing, New York.

Warrag, M.O.A. and A.E. Hall. 1984. Reproductive responses of cowpea (Vigna unguiculata (L.) Walp.) to heat stress. II. Responses to night air temperature. Field Crops Res. 8:17-33.

Westgate, M.E. and C.M. Peterson. 1993. Flower and pod development in water-deficient soybeans (Glycine $\max$ L. Merr.). J. Expt. Bot. 44:109-117.

Wien, H.C. 1990. Screening pepper cultivars for resistance to flower abscission: A comparison of techniques. HortScience 25:1634-1636.

Wien, H.C., A.D. Turner, and S. Yang. 1989. Hormonal basis for low light intensity-induced flower bud abscission of pepper. J. Amer. Soc. Hort. Sci. 114:981-985. 